May 2002

\title{
Health sector reform in South Asia: new challenges and constraints
}

Anwar Islam

Aga Khan University

MZaffar Tahir

Aga Khan University

Follow this and additional works at: https://ecommons.aku.edu/pakistan_fhs_mc_chs_chs

\section{Recommended Citation}

Islam, A., Tahir, M. Z. (2002). Health sector reform in South Asia: new challenges and constraints. Health Policy, 60(2), 151-169.

Available at: https://ecommons.aku.edu/pakistan_fhs_mc_chs_chs/472 


\title{
HeAlth policy
}

Health Policy 60 (2002) 151-169

www.elsevier.com/locate/healthpol

\section{Health sector reform in South Asia: new challenges and constraints}

\author{
Anwar Islam ${ }^{\mathrm{a}, *}$, M. Zaffar Tahir ${ }^{\mathrm{b}}$ \\ ${ }^{a}$ Health Systems Division, Department of Community Health Sciences, The Aga Khan University, \\ Karachi, Pakistan \\ ${ }^{\mathrm{b}}$ Department of Community Health Sciences, The Aga Khan University, Karachi, Pakistan
}

Received 25 February 2001; accepted 12 September 2001

\begin{abstract}
In early 1990s, Jamison, Mosley and others concluded that a profound demographic and consequent epidemiological transition is taking place in developing countries. According to this classical model, by the year 2015, infectious diseases will account for only about $20 \%$ of deaths in developing countries as chronic diseases become more pronounced. These impending demographic and epidemiological transitions were to dominate the health sector reform agenda in developing countries. Following an analysis of fertility, mortality and other demographic and epidemiological data from South Asian and other developing countries, the paper argues that the classical model is in need of re-evaluation. A number of new 'challenges' have complicated the classical interplay of demographic and epidemiological factors. These new challenges include continuing population growth in some countries, rapid unplanned urbanization, the HIV/AIDS pandemic in Sub-Saharan Africa (and its impending threat in South Asia), and globalization and increasing marginalisation of developing countries. While the traditional lack of investment in human development makes the developing countries more vulnerable to the vicissitudes of globalization, increasing economic weakness of their governments forces them to retreat further from the social sector. Pockets of poverty and deprivation, therefore, persist giving rise to three simultaneous burdens for South Asia and much of the rest of the developing world: continuing communicable diseases, increasing burden of chronic diseases, and increasing demand for both primary and tertiary levels of health care services. While these complex factors, on the one hand, underscore the need for health sector reform, on the other, they make the task much more difficult and challenging. The paper emphasizes the need to revisit the classical model
\end{abstract}

* Corresponding author. Tel.: + 92-21-493-2095; fax: +92-21-493-4294.

E-mail address: anwar.islam@aku.edu (A. Islam). 
of demographic and epidemiological transition. It is argued that the health sector in developing countries must be aware of and effectively address these 'new challenges'. Although it has included data from many developing countries, the focus is primarily on South Asia. (C) 2002 Elsevier Science Ireland Ltd. All rights reserved.

Keywords: Demographic transition; Epidemiological transition; Debt burden

\section{Introduction}

In recent years, almost all countries, including those in South Asia, have embarked on health sector reform, in varying degrees. The goals of health sector reform, in a formal sense, remain the achievement of efficiency, improving quality, preserving or promoting equity, and generating new resources for health care. However, the 'urge' to reform varies from country to country. Often reform is initiated by a conscious policy to strengthen or improve the health care system. In some cases, the urge for reform comes from a desire to join the global market through 'economic liberalization'. In an increasing number of developing countries, like Pakistan, who are currently faced with precarious economic situation, social sector reform is dictated more by donor agencies, primarily the World Bank and the IMF, than by any rational policy decision. Consequently, such reform seldom takes into account broader social, economic, demographic and epidemiological changes that have serious implications for the health sector [14].

The paper critically examines the implications of four interconnected forces on the health sector in South Asia and other developing countries-economic globalization and information/communication revolution, demographic transition, epidemiological transition, and urbanization. It argues that the classical notion of demographic transition leading to epidemiological one did not materialized fully in developing countries. This is particularly so in the countries of South Asia. The process is made much more complex by the forces of unplanned urbanization, globalization and information-communication revolution with serious implications for health sector reform. Although some figures from other countries have often been noted, the focus remains on Pakistan, India and Bangladesh.

\section{Demographic-epidemiological transition: the classical model}

A number of scholars, such as Jamison, Mosley, and Henderson [2] have aptly documented the relationship between demographic transition, epidemiological transition and health transition. In the World Bank's seminal book [3], the authors (Jamison, Mosley, Measham and Bobadilla) presented the following model to illustrate the relationship between these three transitions (Fig. 1). 
In short, with increasing urbanization and industrialization (and expanding education and improved medical and public health technology), the fertility declines with a resulting aging of the population. Concurrently, there is a decline in mortality attributable to infectious diseases and a corresponding increase of that from chronic diseases. This classical model obviously derives from the historical trend observed in the developed countries since the industrial revolution some two hundred years ago.

The model has its own logic and dominated much of the thinking of developing country health researchers and scholars over the last two decades. It must be recognized that changes in mortality, fertility and in the age structure of the population along with the social and economic changes outlined in this classical model would have significant implications for health and health care. The demographic transition is to be followed by an epidemiological transition in which the burden of disease will shift from infectious to chronic diseases. With the aging of the population, the causes of mortality, in the long run, are sure to change from infectious diseases to chronic ones. Jamison [4] predicted that in developing countries mortality attributable to infectious diseases would decline from $39 \%$ in 1985 to $19 \%$ by 2015 . Chronic diseases, correspondingly, are expected to increase their share in mortality (Table 1). These epidemiological and demographic changes would drive the health sector reform agenda [5].

Over the last forty years, all regions of the developing world had been experiencing a demographic transition. According to the World Bank [6], in Low-income economies, the total fertility rate (TFR) declined from 6.0 in 1970 to 3.8 in 1991. By the year 2000, it is projected to decline further to 3.2. During the same period,

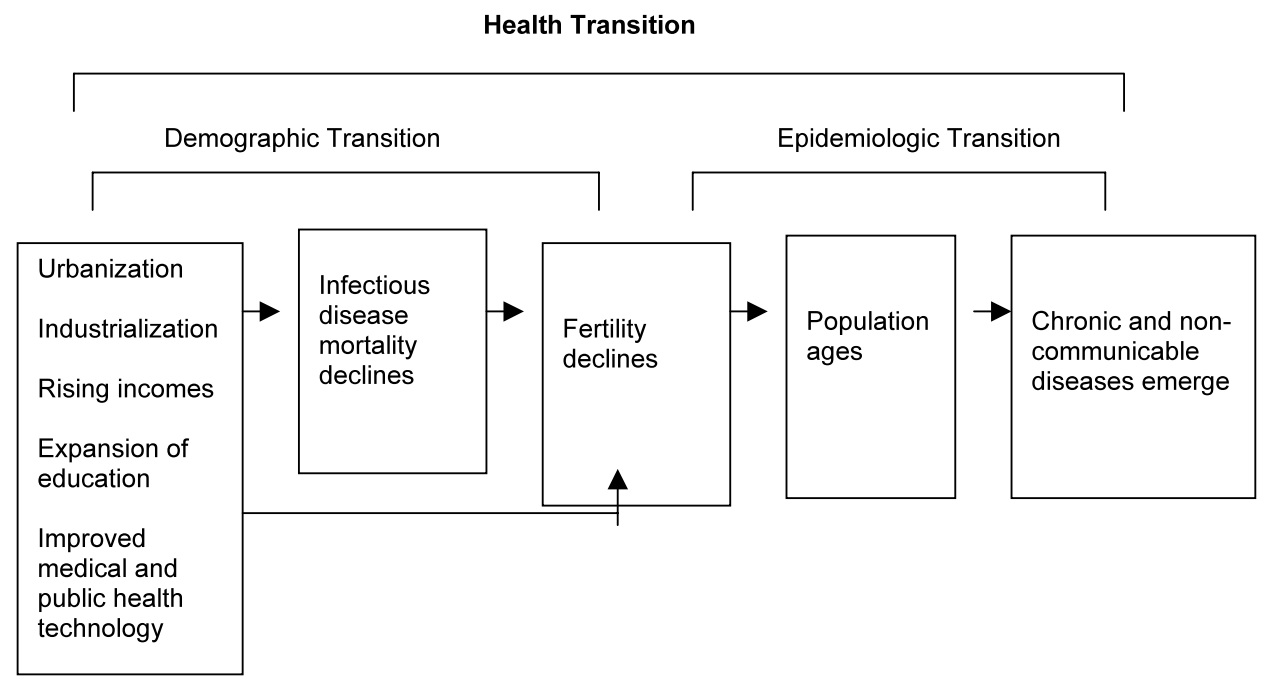

Fig. 1. Source: Jamison, Mosley, Measham and Bobadilla, Disease control priorities in developing countries, World Bank, Washington DC, 1993. 
Table 1

Shifting burden of disease 1985-2015

\begin{tabular}{|c|c|c|c|c|}
\hline \multirow[t]{2}{*}{ Disease category } & \multicolumn{2}{|c|}{ Developed $(\%)$} & \multicolumn{2}{|c|}{ Developing (\%) } \\
\hline & 1985 & 2015 & 1985 & 2015 \\
\hline Infectious & 9 & 7 & 36 & 19 \\
\hline Neoplasm & 18 & 18 & 7 & 14 \\
\hline Circulatory & 50 & 53 & 7 & 14 \\
\hline Pregnancy related & 0 & 0 & 1 & 1 \\
\hline Perinatal & 1 & 1 & 8 & 5 \\
\hline Injury & 6 & 5 & 8 & 7 \\
\hline Other & 15 & 16 & 21 & 19 \\
\hline Total & 100.0 & 100.0 & 100.0 & 100.0 \\
\hline Total deaths (millions) & 12.0 & 14.5 & 37.9 & 47.8 \\
\hline
\end{tabular}

Source: Jamison et al. (1993) [3].

the TFR in Middle-income economies declined from 5.0 in 1970 to 3.2 in 1991 and to 3.1 (projected) in 2000. The South Asian countries underwent similar demographic transition. In India, the TFR was 5.9 in 1960; by 1998, it decreased to 3.1 [7]. The TFR in Bangladesh, declined from 6.7 in 1960 to 3.1 in 1998; while for Pakistan, the corresponding figures are 7.0 and 5.1, a relatively modest decline of $27.1 \%$ over quarter of a century (Table 2 ).

This decline in TFR assumes greater significance when considered in the context of a still expanding base. Over the last thirty years, 'women of childbearing age as a percentage of all women' increased from 44 (1965) to 48 (1991) in Bangladesh; from 48 (1965) to 50 (1991) in India; and from 43 (1965) to 45 (1991) in Pakistan [8]. True to the pattern of demographic transition, the Crude Death Rate (per 1000 population) also declined over the years. For Low-income countries the CDR declined from 14 in 1970 to 10 in 1991 and the corresponding figures for the Middle-income countries are 11 and 8 [6]. These are accompanied by a significant increase in life expectancy at birth in almost all developing countries, including the three South Asian ones. Life expectancy at birth in Bangladesh rose from 44 years in 1970 to 58 years in 1998; while in India, it increased from 49 years to 63 years during the same period. The corresponding figures for Pakistan are 49 and 64 years [7] (Table 3).

Table 2

Total fertility rate decline 1960-1998

\begin{tabular}{llllll}
\hline & Indonesia & Iran & Pakistan & India & Bangladesh \\
\hline 1960 & 5.50 & 7.20 & 7.00 & 5.90 & 6.70 \\
1990 & 3.10 & 4.90 & 6.00 & 3.80 & 4.30 \\
1998 & 2.50 & 2.80 & 5.10 & 3.10 & 3.10 \\
\hline
\end{tabular}

Source: The state of the world's children, UNICEF (2000) [7]. 
Table 3

Decreasing crude death rates and increasing life expectancy in selected developing countries

\begin{tabular}{llclll}
\hline & \multicolumn{2}{l}{ Crude death rate (per 1000 population) } & & \multicolumn{2}{l}{ Life expectancy at birth } \\
\cline { 2 - 3 } \cline { 5 - 6 } & 1970 & 1998 & & 1970 & 1998 \\
\hline Bangladesh & 21.0 & 10.0 & & 44.0 & 58.0 \\
India & 17.0 & 9.0 & & 49.0 & 63.0 \\
Pakistan & 19.0 & 8.0 & & 49.0 & 64.0 \\
Iran & 16.0 & 5.0 & & 55.0 & 69.0 \\
Indonesia & 18.0 & 7.0 & & 48.0 & 65.0 \\
\hline
\end{tabular}

Source: The state of the world's children, UNICEF (2000) [7].

Despite the demographic transition and the corresponding gains, the predictable epidemiological transition is yet to take hold in most countries of the developing world. The classical model put forward by Jamison et al. [3] largely remain unrealized due to certain complicating factors that were not clearly evident even a decade ago. These factors are the new challenges facing the health sector in much of the developing world. These new challenges, on the one hand, underscore the need for health sector reform and, on the other, makes the task of carrying such reform extremely difficult if not impossible.

\section{Health sector reform attempts in South Asia: poverty of planning}

South Asian countries, over the last four or five decades have undertaken some health sector reform initiatives. However, they have achieved little tangible results. Pakistan, for example, undertook three major health sector reform initiatives over the last thirty years. Soon after the Alma Ata declaration, Pakistan introduced the Basic Health Unit (BHU) and Rural Health Center (RHC) initiative as the hub of primary health care. In an hierarchical order, these First Level Care Facilities were to link with the First Level Referral Facilities called Tehsil/ Taluka or Thana Headquarter Hospitals (THQs). Next above were to be the Secondary Level Hospitals at District Headquarters (DHQs). The Tertiary Level Facilities were to top the hierarchy [9]. Conceptually, it was a well-planned scheme. However, acute scarcity of resources at the lowest level, the villages, and at other levels of the hierarchy made the system rather ineffective. A recent survey discovered that only $25 \%$ of the BHUs or RHCs have duly qualified female health professionals; and only about $15 \%$ of the THQs have decent emergency obstetric service [10]. With a view to address this scarcity of health care resource at the village level, in 1994 Pakistan introduced another program called the 'Prime Minister's Program on Family Planning and Primary Health Care'. Recently renamed as 'the National Program', it envisaged placement of trained health workers in each village to provide basic maternal and child health services. These Lady Health Workers (LHW), recruited from within the village, 
were to act as the first point of contact for women. It was planned that there would be 1 LHW for 1000 people by 1998. However, due to lack of financial resources and misplaced priority, Pakistan failed to reach the target. By the end of the century, it had only about 45000 LHWs, far short of 140000 needed to cover the population of almost 140 million. Moreover, while the public health care system is a provincial responsibility, the LHWs remain under the National Program managed by the Federal Ministry of Health. This vertical nature of the program makes integration of health care services, particularly primary health care, at the village level, difficult. Consequently, much of the beds earmarked for women at the THQs remain severely underutilized. A World Bank report in 1997 aptly demonstrated the inefficiency and ineffectiveness of the system [11].

Pakistan's latest reform strategy is the recently announced Devolution Plan. The National Reconstruction Bureau (NRB), set up soon after the military takeover in October 1999, announced the plan for devolution of power to elected governments at the district level throughout the country. The NRB found the existing system to be 'colonial' in nature and perpetuating the 'rural-urban divide'. It concluded: 'in the existing system of governance at the local level, the province governs the districts and Tehsils directly through the bureaucracy at the division, district and Tehsil levels. And the local government for towns and cities exist separately from those of the rural areas. The provincial bureaucratic set ups are the designated 'controlling authorities' of the local governments, and tend to undermine and over-ride them, which breeds a colonial relationship of 'ruler' and 'subject'. The separate local government structures engender rural-urban antagonism, while the administration's role as 'controlling authorities' accentuates the rural-urban divide' [12].

The devolution plan is an answer to these 'two structural and systemic disjoints'. It is meant to introduce 'one coherent structure in which the district administration and the police are answerable to the elected chief executive of the district'. Although local elections are being held in stage, the precise structural framework of the local government envisaged at the district level is yet to be fully spelled out. Nevertheless, NRB is emphatic in declaring that 'The Local Government is based on five fundamentals: devolution of political power, decentralization of administrative authority, deconcentration of management functions, diffusion of the powerauthority nexus, and distribution of resources to the district level. It is designed so that the genuine interests of the people are served and their rights safeguarded. The new system will create an enabling environment in which people can start participating in community welfare and be the masters of their own destiny' [12].

The Devolution Plan, it should be noted, has used four different terms to refer to the soon-to-be introduced governance system: devolution (political power), decentralization (administrative authority), deconcentration (management functions), and diffusion (power-authority nexus). These terms indicate different levels of decisionspace to be accorded in different aspects to the new local government. While the intended decision-space (in the planned devolution exercise) is much wider in terms of political power, it is much narrower in the sphere of management functions [12]. These functional issues will definitely be further discussed and refined as the 
devolution process is implemented. The devolution exercise, undoubtedly, will have significant implications for the health sector. It calls for the abolition of the 'division' as an 'administrative tier' necessitating the abolition of the existing position of Divisional Director General of Health. The Plan creates a powerful position of District Coordination Officer (DCO) representing the provincial bureaucratic structure at the district level. Although the elected Zila Nazim will be the executive head of the district with some limited supervisory 'control' over the DCO (such as, premature transfer, performance appraisal), it is the DCO who would oversee all government services at the district level. According to the Devolution Plan, health services to be delivered at the district level include: 'Public Health, Environment, Basic and Rural Health Units, Child and Women Health, and Population Welfare. The Medical Superintendent(s) of hospitals will also function under this office' [12].

It is apparent that the Devolution Plan has the potential to bring about significant changes in the way health care services are managed and delivered at the district level. However, it is a political plan, devised by a military government seeking legitimacy, with the declared intention of 'introducing genuine' democracy in the country. All political parties are opposed to the Plan and public enthusiasm is rather mute. Consequently, the Devolution Plan and its future remain in doubt. Moreover, the dire economic situation in Pakistan makes the sustainability of district governments highly questionable. Even LHWs (federal government employees) often complain of not receiving their salaries for months at a time [13]. Non-payment of salaries due to lack of funds seems to be more common among provincial government employees. Under these circumstances, the viability of district governments is a wide open question.

Bangladesh, since 1970s, initiated a number of health sector programs. Perhaps the most successful and widely acclaimed is the National Family Planning Program. It has 'achieved an impressive fertility decline since the mid 1980s. The TFR halved from around seven in the 1970s to 3.3 in 1996-1997. Bangladesh's fertility decline has been particularly impressive, given that the country lacks many of the socioeconomic conditions that have historically marked fertility decline' [14]. Unreserved political commitment to the family planning program since gaining independence from Pakistan in 1971, contributed significantly to this success.

In other areas of health care, however, Bangladesh showed little initiative. The family planning program remained so paramount in terms of its importance that it consumed bulk of the resources of the state. Non-government organizations in Bangladesh also, by and large, concentrated on 'development' related issues (such as, income generation through microcredit, or adult education) rather than on health. The Gonoshasthya Kendra (People's Health Center) is the only NGO in Bangladesh that had been involved in the health sector since its inception during the struggle for independence in 1971. Popularly known as GK, it has grown into a large health institution providing primary health care, health education, illness prevention and secondary level curative care. It has an extensive social insurancebased network of primary health care system in villages around Savar, outside the capital Dhaka, including a pharmaceutical factory [15]. 
Nevertheless, for the first decade of its life Bangladesh largely ignored the issue of health sector reform. In 1982, following the recommendations of an Expert Committee, the then military government of Bangladesh promulgated a Drug (Control) Ordinance. 'The policy's basic strategy was to exclude all non-essential drugs from the country, rather than to promote essential drugs in the public sector while allowing the coexistence of a broader private market. The policy created a restricted national formulary of 150 essential drugs and 100 specialist drugs, with 12 at the health post level, 45 for primary health care, and the full list at tertiary hospitals. The act banned about 1700 drugs from production or sale. The ordinance also included measures to promote local manufacture and to restrict foreign firms within Bangladesh' [16]. However, faced with stiff opposition from the medical establishment within the country, and multinational drug companies, the military government had to dilute the policy significantly. The fact that it was a military government that lacked legitimacy also contributed to this fiasco. The same military regime introduced a new national health policy that proposed radical changes in the health care system. This time too, the regime faced stiff opposition from the medical establishment and other interest groups within the country. Around this time, a mass movement against military rule gained momentum and the regime fell within a year. With the fall of the military dictatorship, the health policy also unraveled.

Bangladesh did not embark on any other major health sector reform for almost a decade. In late 1990s, the government took an initiative to introduce 'comprehensive reproductive health services' at the Thana level (the lowest level of the administrative structure with a police headquarter). As of 1998, Bangladesh had 493 Thanas (also called Upzilla) and the new initiative calls for the establishment/ enhancement of the Thana level secondary hospital with adequate women's and children's health care facilities, including emergency obstetric services by the year 2003. However, acute scarcity of resources and inefficiency of the system are making it difficult to achieve the target. It is important to note that Bangladesh has more physicians ( 1 doctor per 4671 people) than nurses (1 nurse per 8066 people) or midwives (1 per 9300 people). Its per capita government expenditure on health and family welfare (includes the family planning program) was only Taka 132 (or \$3.50) in 1996-1997 [17]. This represents a slight decline in government expenditure on health and family welfare from the previous year (it was Taka 139 per capita in 1995). It is too early to predict the ultimate fate of this new initiative.

India, the biggest South Asian country, is a diverse land with an estimated (2000) population of more than 1 billion distributed in an area of more of 3.16 million square kilometers. Seventh largest country in the world in landmass, India is politically divided into 25 States, each with substantial autonomy, and seven Union Territories with lesser degree of autonomy. The Indian States differ greatly in term of size (geographic area), population volume and characteristics (linguistic and religious distribution of population) and, most importantly, in terms of their level of social and economic development. A vast majority of its population $(73.2 \%$, 1998 ) is still live in rural areas. Despite macroeconomic growth since independence in 1947, three-fourths of India's population is estimated to live below or at 
subsistence level, most of them in rural areas. India's rapid population growth, which increased from 340 million in 1951 to 844 million in 1991, to 984 million in 1998 and crossed the billion mark sometime in 1999, is partly responsible for this continued poverty despite macroeconomic growth.

This vastness and diversity of the Indian federating units made it difficult for the central government to introduce and finance any national-wide comprehensive health sector reform. Between 1947 and 1980, the Indian government formed a number of committees to come up with strategic policy directions for the health care system. The Bhore Committee of 1946 was constituted by the departing British colonial power. This was followed by the Mudaliar Committee of 1961, the first national health committee set by independent India. The Jain Committee (1966), the Kartar Singh Committee (1974), the Srivastava Committee (1975) and finally the ICMR-ICSSR Joint Panel of 1980-all recommended various measures to strengthen the health care system. All these committees emphasized the provision of universal primary health care to all Indians irrespective of their place of residence or economic means. In response, India came out with its first National Health Policy in 1983 that established the provision of 'universal, comprehensive primary health care services, relevant to actual needs and priorities of the community' as the most important goal [18].

India largely failed to successfully implement this National Health Policy. In States where the state-level governments were committed to the overall thrust of the National Health Policy, the health care system experienced necessary structural and programmatic changes to make it more equitable and preventive in nature. These States, like Kerala, for example, achieved remarkable success in developing an equitable health care system by investing in 'social' sectors (education in particular). Consequently, Kerala has health status indicators that are almost comparable to those of some of the developed countries. On the other hand, other parts of India, primarily its vast rural hinterland, remained most impoverished in terms of leading health status indicators [19]. In short, the National Health policy of 1983 remains largely unfulfilled.

Since the early 1990s, India embarked on the path of 'liberalization' of the economy. This liberalization and the resultant Structural Adjustment Program introduced far-reaching changes in the Indian economy. With privatization of the economy, foreign investment grew, especially from the Non-Resident Indians (NRIs). So far as the health sector is concerned, two parallel changes occurred; steady reduction in the financial contribution from the Central government for health care at the State level and increasing privatization and corporatization of the health care sector. According to a study, the Central government's contribution fell from $19.9 \%$ of the States' health budget during 1974-1982 to only $3.3 \%$ in $1992-1993$ [20]. Liberalization also brought foreign investment in the health sector, particularly in hospital and diagnostics services. Their target was to cater to the curative service needs of the growing middle class. Their focus, therefore, is on tertiary level services with modern diagnostic technology. Needless to say, major metropolitan cities of India are the prime beneficiaries of this corporatization of the health sector [21]. Consequently, the Health care system in India is increasingly 
becoming more inequitable. While almost $74 \%$ of its population live in rural areas, only $31 \%$ of India's hospitals and $20 \%$ of hospital beds are in rural areas. Even dispensaries are in short supply (only 43\%) in rural areas. On the other hand, 68\% of its hospitals and $61 \%$ of the dispensaries are in the private sector. It is apparent that the health sector in India needs fundamental restructuring based on a judicious public-private mix and the principle of equity [22].

\section{Population growth: a continuing challenge}

First of all, in a number of developing countries, the big ones, the population is still increasing quite rapidly and will continue to do so in the foreseeable future. Consequently, the population of these countries will double within the next twenty to forty years straining the available resources. The six biggest developing countries - India, Indonesia, Pakistan, Bangladesh, Nigeria, and Egypt - had a combined population of about 1.7 billion in 1999 [23], more than $28 \%$ of the world's total. With an average growth rate of 2.1\% (1990-1999), the population of these countries will double within the next twenty-five to forty years. The population of Pakistan is expected to double in 24 years, that of India in 37 years, and the population of Egypt and Indonesia in 32 and 43 years, respectively (Table 4). Such a rapid population growth will undoubtedly put pressure on the scarce resources for health care and make the task of health sector reform profoundly challenging and difficult.

\section{HIV/AIDS in Sub-Saharan Africa: social collapse?}

While one part of the developing world is faced with the consequences of rapid population growth, another part is on the verge of total social collapse due to the deaths and destruction brought about by a single catastrophic disease - HIV/AIDS [24]. If the world does not find the political will to respond immediately and

Table 4

Population and growth rate: six largest developing countries

\begin{tabular}{|c|c|c|}
\hline & $\begin{array}{l}\text { Population (millions) } \\
\text { (1999) }\end{array}$ & $\begin{array}{l}\text { Population growth rate (1990-1999) } \\
(\%)\end{array}$ \\
\hline India & 998.1 & 1.8 \\
\hline Indonesia & 209.3 & 1.5 \\
\hline Pakistan & 152.3 & 2.8 \\
\hline Bangladesh & 126.9 & 1.7 \\
\hline Nigeria & 108.9 & 2.5 \\
\hline Egypt & 67.2 & 2.0 \\
\hline Total & 1663.7 & 2.1 \\
\hline
\end{tabular}

Source: World health report, World Health Organization (2000) [23]. 
Table 5

Sub-Saharan Africa: the HIV/AIDS pandemic

\begin{tabular}{lll}
\hline Country & Number infected & $\%$ of Adult population \\
\hline Angola & 110000 & 2.12 \\
Botswana & 190000 & 25.10 \\
Ethiopia & 2500000 & 9.31 \\
Kenya & 1600000 & 11.64 \\
Niger & 61000 & 1.45 \\
South Africa & 2800000 & 12.91 \\
Zimbabwe & 1400000 & 25.84 \\
\hline
\end{tabular}

Source: UNAIDS (1999) [24].

effectively to this pandemic, much of Sub-Saharan Africa will face the prospect of an economic and social collapse within the next quarter of a century. HIV/AIDS pandemic is about to strike other developing countries too, including the giant India. In Sub-Saharan Africa, the issue of health sector is so overwhelmed with this single disease that the issue of reform to improve quality, equity or technical and/or allocative efficiency seems rather comical (Table 5).

\section{Unplanned urbanization: poverty and environmental degradation}

Another 'new' challenge is that of 'unplanned' urbanization. Throughout the developing world, urbanization is on the rise. According to the World Bank, low-income countries experienced an annual growth rate $3.7 \%$ in its urban population throughout the last thirty years (and it is still continuing). The urban population in Low-income countries increased from $18 \%$ in 1970 to $39 \%$ in 1991 . During the same period, the percentage of urban population in middle-income countries went up from 46 to $62 \%$ [23].

Globally speaking, for the first time in human history, urban dwellers are poised to outnumber their rural counterparts. In the Third World, along with overall urbanization, there is an emergence of mega cities, often one or two in a country dwarfing others. In 1950 out of the 20 largest cities in the world, only seven were in developing countries (including Argentina and Brazil). By 1990, 13 of these mega cities were located in the developing countries. It is projected that by the year 2015 , the developed industrialized world would be able to boast about having only three of these 20 mega cities [25]. In 1990, only three cities from the sub-continent, all Indian (Bombay, Calcutta and Delhi) made this elite club of 20. In 2015, there will be five - one each from Pakistan and Bangladesh-joining them. It is projected that by 2015, Bombay will have a population of 27.2 million - the largest city in South Asia. With a population of 20.8 million, Karachi will follow it. Dhaka, with a projected population of 19 million will not be far behind. Calcutta and New Delhi, with a population of 17.9 million each, are the other two metropolises from the sub-continent. Mexico City, Lagos, Jakarta, Cairo, Manila, and Istanbul are 
examples of other fast growing metropolises in the developing world (Table 6). By 2015, these 11 developing country mega cities (excluding those in China, Brazil, and Argentina) will have a combined population of 209 million- $56 \%$ of the total for the 20 mega cities in the world.

Urbanization, in itself, is not the issue. The problem is the nature of urbanization in these countries. Unlike in the developed world, urbanization in developing countries is not the result of industrialization or economic growth, but a consequence of rural poverty and deprivation. People flock to cities in search of a livelihood, however, precarious that could be. Draught, floods or cyclones in rural areas push a large number of people every year to migrate to the cities, primarily to the capital or the biggest metropolis in the country. These rural migrants put further pressure on the already scarce resources and infrastructure in the cities.

The result is further growth of urban slums, environmental degradation and poverty [26]. It is variously estimated that about $40 \%$ of the people in these Third World metropolises live in slums with little access to safe drinking water, sanitation or primary health care. These slums, in turn, emerge as pockets of deprived humanity. Communicable diseases - resurgent tuberculosis, malaria and di-

Table 6

Mega cities: 20 largest cities of the world (1950, 1990 and 2015 population, in millions)

\begin{tabular}{llllll}
\hline City & $\begin{array}{l}\text { C50 } \\
\text { population }\end{array}$ & & 1990 & City & 2015 \\
& & & population & & population \\
\hline New York & 12.3 & Tokyo & 25.0 & Tokyo & 28.9 \\
London & 8.7 & New York & 16.0 & Bombay & 27.2 \\
Tokyo & 6.7 & Mexico City & 15.0 & Lagos & 24.6 \\
Paris & 5.4 & Sao Paulo & 14.8 & Shanghai & 23.1 \\
Shanghai & 5.3 & Shanghai & 13.3 & Jakarta & 21.1 \\
Buenos Airs & 5.0 & Bombay & 12.0 & Sao Paulo & 20.9 \\
Chicago & 4.9 & Los Angeles & 11.3 & Karachi & 20.8 \\
Moscow & 4.8 & Beijing & 10.9 & Beijing & 19.6 \\
Calcutta & 4.4 & Calcutta & 10.8 & Dhaka & 19.0 \\
Los Angeles & 4.0 & Buenos Aires & 10.7 & Mexico City & 18.9 \\
Beijing & 3.9 & Seoul & 10.7 & New York & 17.9 \\
Osaka & 3.8 & Osaka & 10.3 & Calcutta & 17.9 \\
Milan & 3.6 & Rio de Janeiro & 9.8 & Delhi & 17.9 \\
Mexico City & 3.1 & Paris & 9.7 & Tianjin & 17.0 \\
Philadelphia & 2.9 & Tianjin & 9.7 & Metro Manila & 14.7 \\
Bombay & 2.9 & Jakarta & 9.7 & Cairo & 14.5 \\
Rio de Janeiro & 2.9 & Moscow & 9.2 & Los Angeles & 14.3 \\
& & & & & \\
Detroit & 2.8 & Cairo & 9.0 & Seoul & 13.1 \\
Naples & 2.8 & Delhi & 8.0 & Buenos Aires & 12.2 \\
Leningrad & 2.6 & Metro Manila & 8.0 & Istanbul & 12.1 \\
Total & 92.8 & & 233.9 & & 375.7 \\
\% Increase & & & 152.0 & & 60.6 \\
& & & & & \\
\end{tabular}

Source: The state of the world's population, UNFPA (1996) [25]. 
Table 7

Rate of illiteracy in selected developing countries, 1995

\begin{tabular}{lll}
\hline \multirow{2}{*}{ Country } & \multicolumn{2}{l}{ Illiteracy Rate 1995} \\
\cline { 2 - 3 } & Male & Female \\
\hline Bangladesh & 51 & 74 \\
Egypt & 36 & 62 \\
India & 36 & 65 \\
Ethiopia & 60 & 74 \\
Nepal & 46 & 81 \\
Nigeria & 34 & 53 \\
Pakistan & 46 & 76 \\
Senegal & 57 & 77 \\
\hline
\end{tabular}

Source: The state of the world's children, UNICEF (2000) [7].

arrhea - take a heavy toll in these urban slums. Often lost in the macro-level analysis, the health care systems in these countries are faced with the new challenge of providing essential primary health care services to the impoverished growing slum dwellers.

\section{Investment in the social sector: historical neglect}

Most of the developing countries, especially those in South Asia and Africa, traditionally made little investment in the social sector like education and health [27-29]. Consequently, these societies still suffer from a high level of illiteracy, particularly among women even after four or five decades of independence (Table 7).

Moreover, a number of these countries continue to invest less in education or health than in the military/defense. Again, the South Asian countries, particularly Pakistan and India seem to be most notorious in this regard [28] (Table 8). This lack of development of the human capital, on the one hand, contributed to their continued underdevelopment and, on the other, prolonged the dominance of communicable diseases. The impact of the interconnected pathways of illiteracy, poverty, malnutrition, ill health and disease is most pronounced in these developing countries [30,31]. In other words, these societies, clustered mostly in South Asia, are reaping the 'benefits' of their long history of neglecting the social sector.

While historical neglect of the social sector is crippling these countries, globalization and its apparent negative consequences are fast narrowing the maneuvering room for them [26]. Globalization, contrary the initial euphoria, seems to be increasing the economic muscle of the multinational corporations (MNCs) at the expense of the nation states. Not surprisingly, the economic strength of the Third World countries increasingly looks puny in comparison with that of the MNCs (Table 9). For example, the General Motors in 1999 had a revenue ( $\$ 189.1$ billion) 
Table 8

Public expenditure on health and the military 1995 (selected developing countries)

\begin{tabular}{llc}
\hline Country & Public expenditure (as \% of GDP) on & \\
\cline { 2 - 3 } & Health & Military \\
\hline Bangladesh & 1.2 & 1.7 \\
Egypt & 1.6 & 5.7 \\
India & 0.7 & 2.4 \\
Indonesia & 0.7 & 1.8 \\
Nigeria & 0.3 & 0.8 \\
Pakistan & 0.8 & 6.1 \\
Sri Lanka & 1.4 & 4.6 \\
Zimbabwe & 2.0 & 4.0 \\
\hline
\end{tabular}

Source: World development report, World Bank, 1998/99 [27].

three times larger than the GDP of Pakistan ( $\$ 64.4$ billion). The 1999 revenue of the Departmental store giant Wal-Mart ( $\$ 168.8$ billion) was larger than the combined GDP in that year of Pakistan, Bangladesh, Nigeria, Tanzania, Cambodia, Kenya, Nepal, Vietnam and Zambia [32]. As the MNCs become increasingly stronger, the poorer countries lose their ability to independently develop and implement policies for the social sector.

\section{The debt burden and privatization of health care}

Another direct or indirect consequence seems to be the increasing debt burden of the developing countries [27]. In some countries the debt burden is so high that interest payments on the debt consume an increasingly significant portion of the

Table 9

Globalization: increasing inequality?

\begin{tabular}{lrlrr}
\hline $\begin{array}{l}\text { 1999 Revenue (in billions) } \\
\text { MNCs }\end{array}$ & \multicolumn{2}{l}{ biggest } & Country GDP (billion & 1997 Population (in millions) \\
& \$) & \\
\hline General motors & 189.1 & Pakistan & 64.4 & 137.0 \\
Wal-Mart & 168.8 & Bangladesh & 32.8 & 124.0 \\
Exxon-Mobil & 163.9 & Tanzania & 6.7 & 31.0 \\
Ford motors & 162.6 & Nigeria & 36.5 & 118.0 \\
General electric & 111.6 & Cambodia & 3.1 & 11.0 \\
IBM & 87.5 & Egypt & 75.5 & 60.0 \\
Citigroup & 82.0 & Kenya & 9.9 & 28.0 \\
AT \& T & 62.4 & Nepal & 4.9 & 23.0 \\
Philip Morris & 61.8 & Vietnam & 4.5 & 77.0 \\
Boeing & 58.0 & Zambia & 3.6 & 9.0
\end{tabular}

Sources: MNCs, the daily dawn, Karachi, April 30, 2000; GDP/population, world development report, World Bank, 1998/99 [27]. 
Table 10

The debt burden: a growing constraint

\begin{tabular}{|c|c|c|c|}
\hline \multirow[t]{2}{*}{ Country } & \multicolumn{2}{|c|}{ External debt (total millions of $\$$ ) } & \multirow{2}{*}{$\begin{array}{l}\text { Present value ( } \% \text { of GNP) } \\
1996\end{array}$} \\
\hline & 1980 & 1996 & \\
\hline Pakistan & 9931 & 29901 & 39 \\
\hline Nigeria & 8921 & 31403 & 114 \\
\hline Bangladesh & 4230 & 16083 & 30 \\
\hline India & 20581 & 89827 & 22 \\
\hline Kenya & 3383 & 6893 & 64 \\
\hline Egypt & 19131 & 31403 & 35 \\
\hline Nepal & 205 & 2413 & 26 \\
\hline Zambia & 3261 & 7113 & 161 \\
\hline Tanzania & 2452 & 7412 & 114 \\
\hline Jordan & 1971 & 8118 & 110 \\
\hline Syria & 3552 & 21420 & 120 \\
\hline
\end{tabular}

Source: World development report, World Bank, 1998/99 [27].

budget. Pakistan's external debt in 1996 stood at 39\% of its GNP, while for Bangladesh, foreign debt amounted to 30\% of its GNP in 1996. The external debt of these two South Asian countries is rising each year. On the other hand, the external debt burden of Nigeria and Tanzania stood at 114\%, of their respective GNP in 1996. Zambia's external debt burden in 1996 was more than $161 \%$ of its GNP (Table 10). These highly indebted countries spend an enormous amount of their resources in servicing their debts leaving little resources for other public sectors. The government of Pakistan, for example, spends $45 \%$ of its budget on servicing its external debt. In other words, the government of Pakistan is literary left with little resources to devote to health or education. It may be recalled, Pakistan spends a high proportion of its resources on national defense.

The debt burden is seriously reducing the ability of these countries to finance essential health and other services. Consequently, governments are 'downloading' these services to the private sector [33,34]. In most developing countries, health care is being increasingly dominated by the private sector [20-22] - out-of-pocket expenses outstripping public expense on health care. In India, a whooping $87 \%$ of the expenses on health care is 'private' [27].

In Pakistan, the private sector accounts for $77 \%$ of the total health care expenses (Table 11). Private resources, by its very nature, are primarily directed at tertiary level care. As a private sector entrepreneur would prefer to build and run a for-profit hospital rather than a Basic Health Unit in a rural setting, individuals too are more willing to spend their 'pocket money' on surgery rather than health promotion/illness prevention exercise. This shifting of burden for health care from the public to the private sector, therefore, disproportionately affect primary health care services including health promotion and illness prevention activities. Conversely, health is increasingly becoming a private good to be available as a commodity to the people who can afford the price. This leaves the vast majority of 
the poor and the disadvantaged at the mercy of the market forces. As communicable diseases and poverty are more closely linked, this process of privatization increases the burden of the poor and the disadvantaged.

The information/communication revolution that marks the current era also promotes tertiary level care. Multi-channel television and the Internet seldom carry much on the virtue of safe drinking water or sanitation. However, they do demonstrate the value of high-tech surgery and that of 'exotic' drugs like viagra. In short, the information-communication revolution refocuses the attention of the health care system on tertiary level services that are, by definition, more expensive than essential public health.

\section{Conclusions}

The classical model propounded by Jamison and others rightly predicted that the developing countries are undergoing a demographic as well as epidemiological transition. Consequently, chronic diseases will account for an increasingly greater portion of morbidity and mortality than communicable diseases. To a certain point and primarily at the macro level, these shifts are taking place. However, the classical model needs to be revisited and reviewed in the context of new realities. Developing countries are confronted with new challenges and constraints that adversely affect the health care systems making the predicted epidemiological transition yet to take hold.

Unplanned urbanization resulting into slums, poverty and environmental degradation is one such challenge. Concentrated in slums, the poor and the disadvantaged suffer from a disproportionate share of existing and resurgent communicable diseases. Globalization, on the other hand, is increasing inter- and intra-national inequities. As multinational corporations become more powerful, the nation states in the developing world lose their ability to influence policy or programs. Nation

Table 11

The health systems: increasing private sector role

\begin{tabular}{|c|c|c|c|c|c|}
\hline \multirow[t]{2}{*}{ Country } & \multicolumn{2}{|c|}{ Expenditure on health care } & \multicolumn{3}{|c|}{ Per capita expenditure in $\$$} \\
\hline & Public (\%) & Private $(\%)$ & Public & Private & Total \\
\hline Bangladesh & 46 & 54 & 6 & 7 & 13 \\
\hline Egypt & 27 & 73 & 12 & 32 & 44 \\
\hline India & 13 & 87 & 4 & 19 & 23 \\
\hline Indonesia & 37 & 63 & 8 & 10 & 18 \\
\hline Nepal & 26 & 74 & 2 & 6 & 8 \\
\hline Nigeria & 28 & 72 & 8 & 22 & 30 \\
\hline Pakistan & 23 & 77 & 4 & 13 & 17 \\
\hline Uganda & 35 & 65 & 5 & 9 & 14 \\
\hline Vietnam & 20 & 80 & 3 & 14 & 17 \\
\hline
\end{tabular}

Source: World development report, World Bank, 1998/99 [27]. 
states, therefore, can hardly initiate credible health sector reform. Moreover, increasing debt burden is seriously eroding the financial viability of nation states. As debt servicing is taking an increasing portion of their budgets, developing countries find it extremely difficult to allocate sufficient resources for the health sector. Consequently, the health sector is increasingly being dominated by the private sector. Needless to say, the private sector is more inclined to invest in tertiary level care than primary health care. Information and communication revolution epitomized by the Internet and other forms of mass media also reinforces the 'glamour' of high-tech care raising expectations among the people in developing countries.

Two conclusions can be reached. One, the classical model of demographic transition leading to an epidemiological one is not taking place as smoothly or rapidly as predicted in most developing countries. Second, the health care systems in these countries are faced with multiple new challenges - unplanned urbanization, the HIV/AIDS pandemic and globalization leading to increased marginalization and an information-communication revolution that boost expectation for high-tech interventions. The nation states in the developing world are fast abandoning the health care turf to the private sector leading to further degradation of essential public health. Consequently, much of the developing world is faced with three burdens simultaneously - the burden of rapidly growing population, that of still continuing and/or resurgent communicable diseases and the added burden of chronic diseases. Quite often, disease burdens are concentrated in 'pockets of poverty' — urban slums and/or rural hinterlands. Health sector reform, in order to protect/promote equity, must identify these pockets of poverty, environmental degradation and (communicable) disease at the sub-national level. In other words, data must be analyzed at the micro-level, as national level macro data do not always portray the situation correctly.

Moreover, the developing countries are fast losing the flexibility to set policies and programs according to their unique needs. These new challenges, on the one hand, reinforces the need for health sector reform and, on the other, demonstrates the constraints that the system must overcome in order to initiate any meaningful change.

\section{References}

[1] Cassels A, Health sector reform: key issues in less developed countries. Discussion Paper for Forum on Health Sector Reform. Geneva: World Health Organization, 1995.

[2] Mosley WH, Jamison DT, Henderson DA. The health sector in developing countries: problems for the 1990s and beyond. Annual Review of Public Health 1990;11:335-58.

[3] Jamison DT, Mosley WH, Measham AR, Bobadilla JL, editors. Disease control priorities in developing countries. New York: World Bank, Oxford University Press, 1993.

[4] Jamison DT. Disease control priorities in developing countries: an overview. In: Jamison DT, Mosley WH, Measham AR, Bobadilla JL, editors. Disease control priorities in developing countries. Washington, DC: World Bank, 1993 (Chap. 1). 
[5] Berman P. Health sector reform: making health development sustainable. In: Health sector reform in developing countries-making health development sustainable. Boston, MA: Harvard School of Public Health, Harvard University Press, 1995.

[6] The World Bank. World Development Report 1993: Investing in health. Washington, DC: Oxford University Press, 1993.

[7] United Nations Children's Fund. The State of the World's Children, 2000.

[8] National Institute of Population Studies. Pakistan Demographic and Health Survey 1990-91. Islamabad, 1992.

[9] Siddiqi S, Kielmann AA, Khan SM, Nabeela Ali, Ghaffar A, Unaiza Sheikh, Zubya Mumtaz. The effectiveness of patient referral in Pakistan, Health Policy and Planning, 16(2): 193-198.

[10] Aga Khan University. Family health project assessment report, 2000, in press.

[11] World Bank. Pakistan: towards a health sector strategy. health, nutrition and population unit, South Asia region, Washington, DC, 1997.

[12] National reconstruction Bureau. Local Government Plan 2000. Government of Pakistan, Chief Executive Secretariat, August 14, 2000.

[13] Islam, Anwar, Malik FA, Shazia Basaria, Strengthening primary health care and family planning services in Pakistan: some critical issues, 2001, submitted for publication.

[14] Caldwell, Bruce, Barkat-e-Khuda. The first generation to control family size: understanding Bangladesh's fertility decline from the perspective of the participants. In: Kane Thomas T, Barkat-e-Khuda, Phillips James F, editors. Reproductive health in rural Bangladesh. Dhaka, Bangladesh: ICDDR, B, 1997.

[15] Gonoshasthya Kendra. Annual Report 1998. Dhaka, Bangladesh, 1999.

[16] Reich, Michael R. Bangladesh pharmaceutical policy and politics. Health Policy and Planning, 9(2): $130-143$.

[17] Bangladesh Bureau of Statistics. Statistical Pocketbook 1997. Dhaka, Bangladesh, 1998.

[18] Government of India. Ministry of Health and Family Welfare. The National Health Policy, 1983.

[19] Amartya Sen. Development as freedom. New York: Anchor Books, 1999.

[20] Duggal Ravi, Sunil, N., Vadair, A., Health expenditure across States (Part I and Part II). Economic and Political Weekly 1995; XXX (15) and XXX (16).

[21] Purohit BC. Private initiatives and policy options: recent health system experience in India. Health Policy and Planning, 16(1): 87-97.

[22] Duggnal Ravi. Priorities for Health Reforms in India. Paper at the 3rd International Conference on Priorities in Health Care, Amsterdam, November 24, 2000, in press.

[23] World Health Organization. World Health Report, 2000.

[24] UNAIDS. Annual Report, 1999.

[25] United Nations Population Fund. State of the World's Population 1996. New York: Oxford University Press, 1996.

[26] Arif Hasan. Understanding Karachi: planning and reform for the future. Karachi, Pakistan: City Press, 1999.

[27] World Bank. Knowledge for Development: World Development Report 1998/99. Washington, DC, Oxford University Press, 1999.

[28] Human Development Centre (Islamabad). Human Development in South Asia 1998. Karachi: Oxford University Press, 1998.

[29] World Bank. Poverty and Human Development, Washington, DC: Oxford University Press, 1980.

[30] United Nations Development Program. Human Development Report 1997. New York: Oxford University Press, 1997.

[31] United Nations Development Program. Human Development Report 1998. New York: Oxford University Press, 1998.

[32] The Daily Dawn. Multi-National Corporations. Karachi, April 30, 2000. 
[33] Berman P. Rethinking health care systems: private health care provision in India. Data for decision-making project. Boston, MA: Harvard School of Public Health, 1997.

[34] World Bank. Pakistan: towards a health sector strategy. Health, nutrition and population unit, South Asia region report no. 16695, Washington, DC, 1997. 